\title{
Ceramic Barrier Layers for Flexible Thin Film Solar Cells on Metallic Substrates: A Laboratory Scale Study for Process Optimization and Barrier Layer Properties
}

\author{
Jose-Maria Delgado-Sanchez ${ }^{1,}$, Nuria Guilera ${ }^{2}$, Laia Francesch $^{2}$, Maria D. Alba ${ }^{3}$, Laura Lopez ${ }^{2}$, \\ Emilio Sanchez ${ }^{1}$ \\ ${ }^{1}$ Abengoa Solar New Technologies S.A., Soland Center, Ctra. A472 km 6, 418oo Sanlucar la Mayor, Sevilla (Spain) \\ ${ }^{2}$ CETEMMSA Technological Centre, Av. Ernest Lluch 36, E-08302 Mataró (Spain) \\ ${ }^{3}$ Instituto Ciencia de los Materiales de Sevilla (CSIC-US). Avda. Americo Vespucio, 49, 410o8 Sevilla (Spain)
}

KEYWORDS: Flexible substrate, metallic substrate, barrier layer, thin film solar cells, electric insulator, breakdown voltage

\begin{abstract}
Flexible thin film solar cells are an alternative to both utility-scale and building integrated photovoltaic installations. The fabrication of these devices over electrically conducting low-cost foils requires the deposition of dielectric barrier layers to flatten the substrate surface, provide electrical isolation between the substrate and the device, and avoid the diffusion of metal impurities during the relatively high-temperatures required to deposit the rest of the solar cell device layers. The typical roughness of low-cost stainless-steel foils is in the hundred-nanometer range, which is comparable or larger than the thin film layers comprising the device and this may result in electrical shunts that decrease solar cell performance. This manuscript assesses the properties of different single-layer and bilayer structures containing ceramics inks formulations based on $\mathrm{Al}_{2} \mathrm{O}_{3}$, $\mathrm{AlN}$ or $\mathrm{Si}_{3} \mathrm{~N}_{4}$ nanoparticles and deposited over stainless-steel foils using a rotogravure printing process. The best control of the substrate roughness was achieved for bilayers of $\mathrm{Al}_{2} \mathrm{O}_{3}$ or AlN with mixed particle size, which reduced the roughness and prevented the diffusion of metals impurities but AlN bilayers exhibited as well the best electrical insulation properties.
\end{abstract}

\section{INTRODUCTION}

Photovoltaic devices allow direct conversion of the sunlight into electricity and are among the most promising renewable energy sources to reach comparable prices to fossil-fuel-based sources, particularly for high-radiation regions. This goal has been achieved for wafer-based photovoltaic technologies through the price reductions resulting from a rapid increase in manufacturing capacity. As an alternative, thin film solar cells are predicted to enable even lower prices for similar manufacturing volumes and have therefore attracted considerable attention in recent years. ${ }^{1}$ Furthermore, thin film solar cells reported conversion efficiencies are nowadays similar or even higher than those reported for multicrystalline siliconbased solar cells. ${ }^{2,3}$ Additionally, thin film cells offer key advantages such as a lower cost rigid substrate such as glass and the possibility of utilizing flexible metallic or polymer-based substrates.

Novel applications for photovoltaics are expected for thin and flexible solar modules, mostly for applications in space, aeronautics and mobile systems. ${ }^{4}$ Significant effort have been devoted to the development of flexible and lightweight thin film modules, ${ }^{5,6,7}$ encouraged by the relatively high small-area cell efficiencies obtained on polymer as well as on metallic substrates. A wide variety of substrates have been investigated, ${ }^{8,9,10,11,12}$ with flexible metal foils being attractive due to their thermal stability, vacuum compatibility and resulting device reliability. Stainless steel foils ranks among the most industrially feasible metal foils for photovoltaic devices due to their lower costs and similar thermal expansion coefficient to those of the solar cell device layered stack. ${ }^{9,10,11}$ 
Recently, high efficiency $(18,7 \%) \mathrm{Cu}\left(\mathrm{In}_{1-\mathrm{x}} \mathrm{Ga}_{\mathrm{x}}\right) \mathrm{Se}_{2}$ (CIGS) flexible solar cells on stainless steel substrates ${ }^{13}$ have been demonstrated to display relatively high proton and electron radiation stability, ${ }^{14}$ low weight and high flexibility. ${ }^{15}$ These foils offer the possibility of continuous roll-to-roll fabrication which can allow for lower cost than sequential in-line processing. Additionally, these substrates can withstand temperatures above $600{ }^{\circ} \mathrm{C}$ without losing their mechanical properties, which in turn allows deposition of the solar cell absorber layer. On the other hand, the diffusion of stainless steel metal impurities, such as Fe, Ni and $\mathrm{Cr}$, into the absorbed layer during a high temperature evaporation process can degrade the cell efficiency, ${ }^{16}$ and barriers layers capable of preventing impurity diffusion are therefore of considerable current interest.

Overall, the fabrication of monolithically integrated thin film photovoltaic modules on electrically conducting substrates requires the deposition of a dielectric barrier. ${ }^{4,17,18}$ These barriers must satisfy requirements such as: (a) to provide electrical insulation between the metal substrate and the monolithically interconnected solar cells; (b) to reduce the diffusion of impurities from the metal substrate into the solar cells; (c) to flatten the substrate original roughness; and; (d) to provide an appropriated thermal and mechanical stability during device processing. ${ }^{4,19}$ These insulation properties are mainly influenced by the barrier thickness, substrate type and deposition process. ${ }^{4}$

Different top-down deposition approaches for these dielectric barrier layers, such as physical vapor deposition or atomic layer deposition, have been investigated. ${ }^{20}$ However, significantly less work has been reported using low-cost sol-gel or printing approaches. Herz et al. ${ }^{21}$ explored the suitability of $\mathrm{Al}_{2} \mathrm{O}_{3}$ dielectric layers deposited by $\mathrm{RF}$ magnetron sputtering, as diffusion barriers for three different metal substrates and found that the concentrations of $\mathrm{Fe}$ and $\mathrm{Cr}$ in the thin film solar cell decreased proportionally with increasing the barrier thickness but were not completely suppressed. Their results suggest an $\mathrm{Al}_{2} \mathrm{O}_{3}$ barrier thickness of $\geq 2 \mu \mathrm{m}$ for $\mathrm{Cr}$ steel and $\geq 1 \mu \mathrm{m}$ for $\operatorname{Kovar}^{\circledR}$ substrates. These relatively thick barrier layers render this approach unappealing as the deposition rates for such dielectric layers are typically low.

The present paper describes the preparation of different ink formulations based on $\mathrm{Al}_{2} \mathrm{O}_{3}, \mathrm{AlN}$ and $\mathrm{Si}_{3} \mathrm{~N}_{4}$ nanoparticles that were deposited over stainless steel foils by means of a low-cost rotogravure printing process using environmental friendly aqueous solvents. The aim of this work is to explore new barriers preparation methods using non-vacuum and low cost techniques which could be considered by stainless steel manufacturer or companies involved in thin-film photovoltaic production.

The properties of single-layer and bilayer coatings from these nanoparticles as efficient barrier layers for thin film solar cells are discussed.

\section{EXPERIMENTAL SECTION}

Materials. Commercial stainless steel foils, AISI430 (ferritic), with $140 \mu \mathrm{m}$ thickness were used as substrate because good adhesion for dielectric barriers had been previously reported for these foils.22 Data corresponding to the chemical composition of $\mathrm{S} 430$ stainless steel substrate are presented in Table 1 . The composition of the stainless steel foil consisted mainly of $\mathrm{Fe}$ and $\mathrm{Cr}$ which could diffuse into the thin film solar cell during high temperature processes and cause degradation of the solar cell efficiency. The metal foil showed a relatively high roughness $(\mathrm{Ra})$ of $220 \mathrm{~nm}$ compared with a typical $\mathrm{Ra}$ of $10-15 \mathrm{~nm}$ for glass substrates. This elevated roughness could affect the insulation properties of the barrier layers.4

For the barrier layer to block the diffusion of impurities, ceramic nanoparticles of $\mathrm{Al}_{2} \mathrm{O}_{3}, \mathrm{AlN}$ and $\mathrm{Si}_{3} \mathrm{~N}_{4}$ were chosen due to their physical properties: (i) compatible Thermal Expansion Coefficient (TEC) to that of the AISI430 foil which directly affected the film adhesion at high temperature, (ii) strong ionic interatomic bonding and nanoparticles character leading to effective impurity blocking, (iii) chemical inertness, (iv) relatively good thermal conductivity, and, (v) good electrical insulator between the metallic substrate and the monolithically interconnected solar cell required for flexible solar modules. $\mathrm{Al}_{2} \mathrm{O}_{3}$ nanoparticles were supplied by Sigma-Aldrich with particle size ranging between $20 \mathrm{~nm}$ and $50 \mathrm{~nm}$. AlN nanoparticles with particle size of $40 \mathrm{~nm}$ were supplied by SkySpring Nanomaterials Inc and those with particle size of $100 \mathrm{~nm}$ were supplied by Sigma-Aldrich. $\mathrm{Si}_{3} \mathrm{~N}_{4}$ nanoparticles with particle size of $20 \mathrm{~nm}$ were supplied by SkySpring Nanomaterials Inc and those with particle size of $50 \mathrm{~nm}$ were supplied by Sigma-Aldrich. The dispersants used for preventing nanoparticle agglomerates were polyacrylic acid, PEG40o and glycerin as a plasticizer, and Triton X-10o as a wetting agent. The solvent was deionized water with a conductivity of $0.055 \mu \mathrm{S} \cdot \mathrm{cm}^{-1}$.

Ink formulation and Thin Film deposition. The inks were prepared from the mixture of predetermined quantities of additives (dispersant and plasticizer) with the ceramic materials $\left(\mathrm{Al}_{2} \mathrm{O}_{3}, \mathrm{AlN}\right.$ or $\left.\mathrm{Si}_{3} \mathrm{~N}_{4}\right)$. The stability of the formulation was studied by the visual observation of sediment formation for periods up to 700 hours. The name, composition and stability of the inks are summarized in Table 2.

Thin films of the ceramic barriers were deposited on the substrates using a rotogravure printing process (also called doctor blade method). In this deposition approach, well-mixed slurry consisting of a suspension of ceramic particles along with other additives (such as binders, dispersants or plasticizers) was placed on a substrate before the blade. Using a constant relative movement between the blade and the substrate, the slurry spread on the substrate to form a thin sheet which resulted in a gellayer upon drying. The blade was operated at speed up to 
$0.2 \mathrm{~m} \cdot \mathrm{s}^{-1}$, with a gap between the blade and the substrate of $50 \mu \mathrm{m}$. Finally, the thin films were sintered in air at 600 ${ }^{\circ} \mathrm{C}$ during $20 \mathrm{~s}$.

Characterization. The ink stabilization was determined by the visual detection of sedimentation degree on time.

The thickness and roughness of the ceramic barriers were measured using a Veeco Dektac profilometer model 150. Using a $3 \mathrm{mg}$ force and a $2000 \mu \mathrm{m}$ scan length, 7 different points of the samples surface were measured to obtain an average roughness $\left(R_{a}\right)$ of the surface.

To study the inks behavior at high temperature a thermal analysis using Thermogravimetry and Differential Scanning Calorimetry (TGA/DSC) was undertaken. 10-15 $\mathrm{mg}$ of the barrier inks were heated in air up to $600{ }^{\circ} \mathrm{C}$ at 10 ${ }^{\circ} \mathrm{C} \cdot \mathrm{min}^{-1}$ and then maintained at $600{ }^{\circ} \mathrm{C}$ during $15 \mathrm{~min}$. Finally the samples were allowed to cool down to room temperature.

Fourier Transform Infrared Spectra (FTIR-ATR) were recorded using the Spectrum 100 system from Perkin Elmer in the range $4000-650 \mathrm{~cm}^{-1}$.

Rheological behavior of the suspensions was investigated using a Rheometer Anton Paar Physica MCR 301. Viscosities of the ink formulations were measured at controlled shear rate (CSR mode) with a rotational speed between 1 and $100 \mathrm{~s}^{-1}$.

X-ray photoelectron spectroscopy (XPS) is an ideal technique for analyzing the surface of ceramic layers and stainless steel, as it allows evaluating the diffusion process of stainless steel elements such as iron at the interface between the substrate and the ceramic layer. A PHI 5500 Multitechnique System (from Physical Electronics) with a monochromatic X-ray source Aluminium $K_{\alpha}$ line with $1486.6 \mathrm{eV}$ and $350 \mathrm{OW}$ ), was used to perform the XPS measurements. The analyzed area was a circle of $0.8 \mathrm{~mm} \mathrm{di-}$ ameter, and the selected resolution for the spectra was $187.5 \mathrm{eV}$ of Pass Energy and o.8 eV/step. In-depth measurements for composition depth profiles were obtained by sputtering the surface with an $\mathrm{Ar}+$ ion source (energy of $4 \mathrm{keV}$ ). A profile analysis was carried out at the surface and at depths of $50 \mathrm{~nm}, 100 \mathrm{~nm}, 150 \mathrm{~nm}$ and $250 \mathrm{~nm}$, respectively.

Ceramic layers were characterized using the ASTM D3359-o9 adhesion test. This test was performed on samples with two and three ceramic layers by subjecting them to a thermal treatment at $600{ }^{\circ} \mathrm{C}$ during 45 minutes and $600{ }^{\circ} \mathrm{C}$ during 20 seconds. The metallic surface was then cut into square sections with a $20 \mathrm{~mm}$ side and to each of them a tape was attached. Then the tape was removed abruptly and the adhesion was assessed by determining whether the film had or not detached from the substrate.

The breakdown voltages of the ceramic barrier layers were measured to characterize the insulation properties. For this propose, a $400 \mathrm{~nm}$-thick Molybdenum (Mo) layer was sputtered over the barrier-coated metal foils. The breakdown voltage was measured by connecting the Mo contacts on the barrier using a steel tip and increasing the voltage between tip and substrate until an electrical breakdown occurred.

\section{RESULTS AND DISCUSSION}

Inks Formulation. Different ink formulations were prepared by varying the relative percentage of additives and the nature of the ceramic nanoparticles. Their stabilities were analyzed by measuring the sediment as a function of time (Table 2).

The $\mathrm{Al}_{2} \mathrm{O}_{3}$ ink formulation with an additive content below $3 \% \mathrm{w} / \mathrm{w}\left(\mathrm{Al}_{2} \mathrm{O}_{3}-\mathrm{I}_{3}\right.$ and $\left.\mathrm{Al}_{2} \mathrm{O}_{3}-\mathrm{I}_{4}\right)$ showed a reasonable stability with the absence of sediment even after a period of one month. However, formulations containing over 3\% $\mathrm{w} / \mathrm{w}$ of additive $\left(\mathrm{Al}_{2} \mathrm{O}_{3}-\mathrm{I}_{1}\right.$ and $\left.\mathrm{Al}_{2} \mathrm{O}_{3}-\mathrm{I}_{2}\right)$ presented sedimentation after one week. The dispersant content was increased in the $\mathrm{Al}_{2} \mathrm{O}_{3}-\mathrm{I}_{3}$ and $\mathrm{Al}_{2} \mathrm{O}_{3}-\mathrm{I}_{4}$ formulations and could be responsible for their absence of sedimentation. Instability of the layers of $\mathrm{Al}_{2} \mathrm{O}_{3}$ with high additive content could also be observed in the measured viscosity (Figure 1a). Stable inks, those that did not exhibit any sedimentation, showed a lower viscosity than the unstable ones (viscosity of 2.5-3 mPa.s vs 11-14 mPa.s). The inks must have properties of high fluidity to allow depositing thin layers. Stable ceramic inks are characterized by the non-Newtonian behavior ${ }^{23}$, shown in Figure 1 which is indicative of an optimal dispersion of the nanoparticles.

Moreover, AlN inks with low additive content exhibited a low stability since sediment appeared after two days. Ink formulations with high additive content showed good stability after one month without sedimentation (AlN-N3 and AlN-N4) because they also contained the highest content of dispersant. In contrast to inks based on $\mathrm{Al}_{2} \mathrm{O}_{3}$, AlN inks are characterized by a higher surface area which results in a higher percentage of dispersant required for the formulation stability. Therefore, both steric and electrostatic repulsion appear to be compensated by the amount of dispersant. The viscosity curves of the stable formulations show a non-Newtonian behavior. ${ }^{23}$ As in the case of the $\mathrm{Al}_{2} \mathrm{O}_{3}$-based inks, the inks show a viscosity behavior suggesting a high stability. However, the viscosities of the AlN inks were lower than corresponding values for the $\mathrm{Al}_{2} \mathrm{O}_{3}$ inks (1.9-2 mPa.s vs 2.5-3 mPa.s), which may be ascribed to a higher content of plasticizer.

In the case of the $\mathrm{Si}_{3} \mathrm{~N}_{4}$ inks, formulations with a $5 \% \mathrm{w} / \mathrm{w}$ of additive $\left(\mathrm{Si}_{3} \mathrm{~N}_{4}-\mathrm{S}_{1}\right.$ and $\left.\mathrm{Si}_{3} \mathrm{~N}_{4}-\mathrm{S}_{2}\right)$ were unstable, generating sediment content after 20 days. In these inks, a high deviation of the viscosity versus the shear stress was observed, which is indicative of their limited stabilities. The $\mathrm{Si}_{3} \mathrm{~N}_{4}-\mathrm{S}_{3}$ and $\mathrm{Si}_{3} \mathrm{~N}_{4}-\mathrm{S}_{4}$ inks, shown in Figure 1c, follow a non-Newtonian behavior, similar to that of the best $\mathrm{Al}_{2} \mathrm{O}_{3}$ and AlN formulations and with an intermediate viscosity (2-2.5 $\mathrm{mPa} \cdot \mathrm{s})$. 
The evolution of the inks with temperatures up to $600{ }^{\circ} \mathrm{C}$ was analyzed by TGA/DSC. The DSC curves are character-

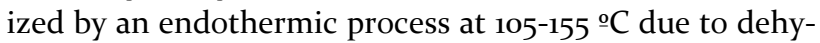
dration followed by an exothermic behavior at $430-440$ ${ }^{\circ} \mathrm{C}$. The endothermic reaction was accompanied by a high weight loss, up to $95 \%$, due to the removal of solvent.24 In the temperature range between $160{ }^{\circ} \mathrm{C}$ and $600{ }^{\circ} \mathrm{C}$, a weight reduction between 2.1 and $4.8 \%$ was observed, which may be ascribed to additive decomposition. Recovered solid powder residues after the measurement had a white color for both $\mathrm{Al}_{2} \mathrm{O}_{3}$ and $\mathrm{Si}_{3} \mathrm{~N}_{4}$, and grey for $\mathrm{AlN}$. These residues were analyzed using FTIR spectroscopy.

The thermal stability of the ink formulation was analyzed by comparing the FTIR spectra of the as-received ceramic materials with those of the DSC residues corresponding to the stables ceramic nanoparticles inks (Figure 2).

The absorption spectrum of the as-received $\mathrm{Al}_{2} \mathrm{O}_{3}$ nanoparticles (Figure 2a) was characterized by resolving the bands in the 650 to $1000 \mathrm{~cm}^{-1}$ range, which suggests the existence of $\mathrm{AlO}_{4}$-tetrahedra and $\mathrm{AlO}_{6}$-octahedra in their structure. No noticeable difference was observed in the IR spectra of the annealed ink formulations.

Figure $2 \mathrm{~b}$ shows the FTIR spectrum of the AIN commercial powder which was characterized by an intense and broad band centered at $890 \mathrm{~cm}^{-1}$ with a shoulder at ca. $760 \mathrm{~cm}^{-1}$. Li et al. ${ }^{25}$ identified the adsorption band at 770 and $800 \mathrm{~cm}^{-1}$ as due to Fröhlich modes of the nanocrystalline AlN. However, this mode can shift from one sample to other because they are quite sensitive to the crystal size and shape (i.e. Fröhlich absorption of cubical particles has a lower frequency than that of spherical particles ${ }^{26}$ and the dielectric constant of the medium. ${ }^{27,28}$ In addition, the broad absorption signal could be due to the existence of a size and shape distribution. The only difference in the spectrum of the annealed ink formulation was a new absorption band at $690 \mathrm{~cm}^{-1}$. This band has been reported to belong to the Al-N band of nanostructured AlN crystals which is close to the bulk mode at $660 \mathrm{~cm}^{-1} .29,30$ According to previous literature, ${ }^{31}$ the existence of bulk mode can be attributed to the particle aggregation to form chainlike structure, which is favored in reduced-sized particles.

The FTIR spectra of as-received $\mathrm{Si}_{3} \mathrm{~N}_{4}$ nanoparticles (Figure $2 \mathrm{c}$ ) is characterized by a wide band in the range between $1300-650 \mathrm{~cm}^{-1}$ composed of the $\mathrm{N}-\mathrm{H}$ wagging mode at $\sim 1150 \mathrm{~cm}^{-1}$ and the Si-N asymmetric stretching mode at $\sim 840 \mathrm{~cm}^{-1} \cdot 32,33$ The decomposition of the Si-N stretching mode into different constituents modes (1071, 905 and 810 $\mathrm{cm}^{-1}$, here) was reported for both silicon-rich ${ }^{34}$ and stoichiometric nitride films. ${ }^{35}$ Scardera et al. ${ }^{36}$ attributed the shoulder in the $1000-1100 \mathrm{~cm}^{-1}$ range to silicon nanocrystals embedded in silicon nitride. No noticeable difference was observed in the IR spectra in the annealed ink formulation which indicated that the treatment did not induce sufficient local bonding disorder. ${ }^{36}$

Ceramic barrier deposited over a metallic substrate. The thickness and surface roughness as a function of the number of deposited ceramic barrier layers with homogeneous particle size are depicted in Figure 3. The thickness of the barrier increased with the number of deposited layers but this dependence was not linear. A decrease in the slope was observed on increasing the number of layers which demonstrated the influence of the substrate nature in the final thickness. ${ }^{37}$ All ceramic barriers exhibited a decreased of the average roughness $\left(R_{a}\right)$ up to a bilayer, while increasing the number of layers did not result in a further decrease of Ra. The minimum Ra measured were $109 \pm 10 \mathrm{~nm}, 106 \pm 14 \mathrm{~nm}$ and $146 \pm 5 \mathrm{~nm}$ for bilayers of $\mathrm{Al}_{2} \mathrm{O}_{3}-\mathrm{I}_{3}, \mathrm{AlN}-\mathrm{I}_{3}$ and $\mathrm{Si}_{3} \mathrm{~N}_{4}-\mathrm{I}_{3}$, respectively. Thus, a relative decrease of the metal substrate roughness $(220 \pm 20 \mathrm{~nm})$ of up to $52 \%$ was inferred. Utilizing this bilayer decreases substrate roughness resulting in improved electrical properties of the thin film cell ${ }^{8}$ and in this respect barrier layers based on $\mathrm{Al}_{2} \mathrm{O}_{3}$ or $\mathrm{AlN}$ are preferable to those based on $\mathrm{Si}_{3} \mathrm{~N}_{4}$.

An exploration of the influence of the particle size of the bilayer on the average roughness was performed on the ceramic barriers based on $\mathrm{Al}_{2} \mathrm{O}_{3}$ and AlN (Figure 4). A combination of small and large particle sizes reduced $\mathrm{Ra}$ after a second layer deposition. Therefore, the formulations with lower Ra were: AlN-N3/AlN-N $4\left(R_{a}=93 \pm 3 \mathrm{~nm}\right.$ and thickness of $1.26 \pm 0.08 \mu \mathrm{m})$ and $\mathrm{Al}_{2} \mathrm{O}_{3}-\mathrm{I}_{3} / \mathrm{Al}_{2} \mathrm{O}_{3}-\mathrm{I}_{4}$ $\left(R_{a}=103 \pm 6 \mathrm{~nm}\right.$ and thickness of $\left.1.39 \pm 0.06 \mu \mathrm{m}\right)$. It is worth noting that these roughness values are quite below those measured for an $\mathrm{Al}_{2} \mathrm{O}_{3}$ barrier deposited using $\mathrm{RF}$ sputtering over a metal substrate. ${ }^{4}$

Both thin barrier layers, $\mathrm{Al}_{2} \mathrm{O}_{3}$ and $\mathrm{AlN}$, displayed a good adhesion to the metal substrate even after thermal treatments at $600^{\circ} \mathrm{C}$ during $45 \mathrm{~min}$. Additionally, no film cracking was observed in the barrier layers after doctor blade deposition. The absence of cracks or exfoliation in annealed samples also suggests a high quality barrier obtained using the previously described procedure.

The ability of both ceramic bilayer barriers (AlN$\mathrm{N}_{3} / \mathrm{AlN}-\mathrm{N}_{4}$ and $\left.\mathrm{Al}_{2} \mathrm{O}_{3}-\mathrm{I}_{3} / \mathrm{Al}_{2} \mathrm{O}_{3}-\mathrm{I}_{4}\right)$ to both reduce the diffusion of impurities from the metal substrate into the solar cell and provide electrical insulation between the metal substrate and the device were explored.

The diffusion of metals atoms through the Mo back contact into the photovoltaic active layers can decrease device efficiency for thin film solar cells fabricated over flexible metal foils. The diffusion of metals atoms can cause enhancement of recombination processes at these metal impurities resulting in a decrease in the collection of carriers at the electrodes. The deposition temperatures required to deposit both the absorber layer and the front contact (typically above $550^{\circ} \mathrm{C}$ ) can result in metal impurity diffusion and therefore diffusion of Fe atoms through the barriers was investigated using XPS. The intensity of both Fe 2p3 and Fe 2p1 XPS signals of a bilayer of AlN-N 3 /AlN-N 4 and a bilayer of $\mathrm{Al}_{2} \mathrm{O}_{3}-\mathrm{I}_{3} / \mathrm{Al}_{2} \mathrm{O}_{3}-\mathrm{I}_{4}$ deposited over AISI 430 stainless steel and heated at 600 을 during $45 \mathrm{~min}$ are shown in Figure 5. For both ceramic barriers, the in- 
tensity of the signals decreases to zero at the surface, which suggests that a barrier of both materials with a thickness of roughly $1.3 \mu \mathrm{m}$ is sufficient to avoid metalimpurity diffusion through the Mo back contact layer.

Finally, the breakdown voltages were measured for both bilayers barriers (AlN-N3/AlN-N 4 and $\mathrm{Al}_{2} \mathrm{O}_{3}-\mathrm{I}_{3} / \mathrm{Al}_{2} \mathrm{O}_{3}-\mathrm{I}_{4}$ and are shown in Figure 6. The values were $32 \mathrm{~V}$ for the $1.39 \mu$ m-thick AlN-N $3 / \mathrm{AlN} \mathrm{N}_{4}$ barriers and $20 \mathrm{~V}$ for the $1.26 \mu \mathrm{m}$-thick $\mathrm{Al}_{2} \mathrm{O}_{3}-\mathrm{I}_{3} / \mathrm{Al}_{2} \mathrm{O}_{3}-\mathrm{I}_{4}$ structures, respectively. These values are similar to those reported for $1 \mu \mathrm{m}$-thick RF-sputtered $\mathrm{Al}_{2} \mathrm{O}_{3}$ barriers, with the advantage that the present work uses low-cost high throughput fabrication methods alone. ${ }^{4}$ Low breakdown voltages suggest a poor electrical insulation behavior of the barriers.

CONCLUSIONS. Ceramic inks using water as solvent have been formulated and the conditions of formulation to ensure stability and an adequate flow have been determined.

The optimum number of layers is a bilayer which is able to decrease the roughness. In this sense, the best formulations were a bilayer of $\mathrm{Al}_{2} \mathrm{O}_{3}-\mathrm{I}_{3} / \mathrm{Al}_{2} \mathrm{O}_{3}-\mathrm{I}_{4}$ or $\mathrm{AlN}-\mathrm{N}_{3} / \mathrm{AlN}$ $\mathrm{N}_{4}$ which also prevented the diffusion of metals through the dielectric barrier. Among them, the bilayer of AlN$\mathrm{N}_{3} / \mathrm{AlN}_{\mathrm{N}} \mathrm{N}_{4}$ exhibited the best insulation properties.

Moreover, an easily scalable deposition technique has been proposed. It has some advantages that ensure their acceptance at industrial scale: low CAPEX, high throughput, non-expensive raw materials and high exploitation efficiency compared to vacuum techniques ones. The chemical solutions employed are REACH rules compatible: nontoxic elements are used and non-contaminant residues are generated.

\section{AUTHOR INFORMATION}

\section{Corresponding Author}

* E-mail: josemaria.delgado@solar.abengoa.com

*E-mail: alba@icmse.csic.es

\section{Notes}

The authors declare no competing financial interest.

\section{ACKNOWLEDGMENT}

We good like to acknowledge Prof. Francisco Villuendas for fruitful discussions. We thank also to F.J Castaño for fruitful discussions and manuscript proof reading.
(1) Contreras, M.A.; Romero, M.J.; Noufi, R. Characterization of $\mathrm{Cu}(\mathrm{In}, \mathrm{Ga}) \mathrm{Se} 2$ Materials Used in Record Performance Solar Cells. Thin Solid Films 2006, 511, 51-54.

(2) Green, M.A.; Emery, K.; Hishikawa, Y.; Wart, W. Solar Cell Efficiency Tables (version 37). Prog. Photovoltaics 2011, 19, 84-92.

(3) Schultz, O.; Glunz, G.W.; Willeke, G.P. Multicrystalline Silicon Solar Cells Exceeding 20\% Efficiency. Prog. Photovoltaics 2004, 12, 553-558.

(4) Hertz, K.; Kessler, F.; Wächter, R.; Powalla, M.; Scneider, J.; Schulz, A.; Schumacher, U. Dielectric Barriers for Flexible CIGS Solar Modules. Thin Solid Films 2oo2, 403-404, 384-389.

(5) Contreras, M.; Egas, B.; Ramanathan, K.; Hiltner, J; Hasson, F.; Noufi, R. Progress Toward 20\% Efficiency in Cu(In,Ga)Sez Polycrystalline Thin-film Solar Cells. Prog. Photovoltaics 1999, 7, 311-316.

(6) Basol, B.M.; Kapur, V.K.; Leidholm, C.R.; Halani, A. Flexible and Light Weight Copper Indium Diselenide Solar Cells on Polyimide Substrates. Sol. Energy Mater. Sol. Cells 1996, 43, 9398.

(7) Tiwari, A.N.; Krejci, M.; Haug, F.J.; Zogg, H. 12.8\% Efficiency $\mathrm{Cu}(\mathrm{In}, \mathrm{Ga}) \mathrm{Se}_{2}$ Solar Cell on a Flexible Polymer Sheet. Prog. Photovoltics 1999, 7, 393-397.

(8) Bermaud, D.; Rudmann, D.; Kaelin, M.; Ermits, K.; Bilger, G.; Dobeli, M.; Zogg, H.; Tiwari, A.N. Flexible Cu(In,Ga)Sez on Al Foils and the Effects of Al During Chemical Bath Deposition. Thin Solid Films 2007, 515, 5857-5861.

(9) Ishizuka, S.; Yamada, A.; Matsubara, K.; Fons, P.; Sakurai, K.; Niki, S. Alkali Incorporation Control in $\mathrm{Cu}(\mathrm{In}, \mathrm{Ga}) \mathrm{Se}_{2}$ Thin Flms Using Silicate Thin Layers and Applications in Enhancing Flexible Solar Cell Efficiency. Appl. Phys. Lett. 2oo8, 93, 12410511241053. 
(10) Ishizuka, S.; Yamada, A.; Islam, M.M.; Shibata, H.; Fons, P.; Sakurai, T.; Akimoto, K.; Niki, S. Na-induced Variations in the Structural, Optical, and Electrical Properties of $\mathrm{Cu}(\mathrm{In}, \mathrm{Ga}) \mathrm{Se} 2$ Thin Flms. J. Appl. Phys. 2009, 106, 0349081-0349086.

(11) Yagioka, T.; Nakada, T. Cd-Free Flexible Cu(In,Ga)Sez Thin Film Solar Cells with ZnS(O,OH) Buffer Layers on Ti Foils. Appl. Phys. Express 2009, 2, 0722011-0722016.

(12) Kessler, F.; Rudmann, D. Technological Aspects of Flexible CIGS Solar Cells and Modules. S. Energy 2004, 77, 685-695.

(13) Chirilă, A.; Buecheler, S.; Pianezzi, F.; Bloesch, P.; Gretener, C.; Uhl, A.; Fella, C.; Kranz, L.; Perrenound, J.; Seyrling, S.; Verma, R.; Nishiwaki, S.; Romanyuk, Y.E.; Bilger, G.; Tiwari, A.N. Highly Efficient $\mathrm{Cu}(\mathrm{In}, \mathrm{Ga}) \mathrm{Se}$ Solar Cells Grown on Flexible Polymer Films. Nat. Mater. 2011, 10, 857-861

(14) Kawakita, S.; Imaizumi, M.; Sumita, T.; Kushiya, K.; Ohshima, T.; Yamaguchi, M. Super Radiation Tolerance of CIGS Solar Cells Demonstrated in Space by MSD-1 Satellite. Proc. 3rd world conference Photovoltaic Energy Conversion, Osaka, 2003, $693-696$.

(15) Otte, K.; Makhova, I.; Braun, A.; Konovalov, I. Flexible Cu(In,Ga)Sez Thin-Film Solar Cells for Space Application. Thin Solid Films 2006, 511-512, 613-622.

(16) Jackson, P.; Hariskos D.; Lotter E.; Paetel S.; Wuerz R.; Menner R.; Wischmann W.; Powalla M. New World Record Efficiency for $\mathrm{Cu}(\mathrm{In}, \mathrm{Ga}) \mathrm{Se}_{2}$ Thin-Film Solar Cells Beyond $\mathbf{2 0} \%$. Prog. Photovoltaics 2011, 19, 894-897.

(17) Guillen C.; Martinez M.A.; Maffiotte C.; Herrero J. Chemistry of CdS/CuInSe ${ }_{2}$ Structures as Controlled by the CdS Deposition Bath. J. Electrochem. Soc. 2001, 11, G6o2-G6o6
(18) Kessler, F.; Hermann D.; Powalla, M. Approaches to Flexible CIGS Thin-Film Solar Cells. Thin Solid Films 2001, 480-481, $491-498$.

(19) Guillemoles J.; Kronik L.; Cahen D.; Rau U.; Jasenek A.; Schock H.W. Stability Issues of Cu(Ga,In)Se-based Solar Cells. J. Phys. Chem. B 2000, 104, 4849-4862.

(20) Bae, D.W.; Gho J.; Shin M.; Kwon S. Effect of Zinc Addition on Properties of Cadmium Sulfide Layer and Performance of Cu(In,Ga)Sez Solar Cells. Thin Solid Films 2013, 535, 162-165

(21) Herz, K.; Eicker, A.; Kessler, F.; Wächter, R.; Powalla, M. Diffusion Barriers for CIGS Solar Cells on Metallic Substrates. Thin Solid Films 2003, 431-432, 392-397.

(22) Thongkham, W.; Pankiew, A.; Yoodee, K.; Chatraphorn, S. Enhancing Efficiency of $\mathrm{Cu}(\mathrm{In}, \mathrm{Ga}) \mathrm{Se}_{2}$ Solar Cells on Flexible Stainless Steel Foils Using NaF Co-evaporation. S. Energy 2013, 92, 189-195.

(23) Bouldin M.; Kulicke W.-M; Kehler H. Prediction of the Non-Newtonian Viscosity and Shear Stability of Polymer Solutions. Colloid Polym. Sci. 1988, 266, 793-805.

(24) Datta, S.; Keller, K.; Schulz, D.L.; Webster, D.C. Conductive Adhesives From Low-VOC Silver Inks for Advanced Microelectronics Applications. IEEE Trans. Compon., Packag., Manuf. Technol. 2011, 1, 69-75.

(25) Li, H.D.; Zou, G.T.; Wang, H.; Yang, H.B.; Li, D.M.; Yu, S.; Wu, Y.; Meng, Z.F. Synthesis and Infrared Study of Nanosized Aluminum Nitride Powders Prepared by Direct Current Arc Plasma. J. Phys. Chem. B 1998, 102, 8692-8695.

(26) LuXon, J.T.; Montgomery, D.J.; Summitt, R. Effect of Particle Size and Shape on Infrared Absorption of Magnesium Oxide Powders. Phys. Rev. 1969, 188, 1345-\&. 
(27) Yamamoto, K.; Tran, C.D.; Shimizu, H.; Abe, K. Optical Surface Phonon Modes in ZnO Small Crystals. J. Phys. Soc. Jpn. $1977,42,587-590$.

(28) Ruppin, R.; Nahum, J. Phonon-plasmon Modes in Small GaN Crystals. J. Phys. Chem. Solids 1974, 35, 1311-1315.

(29) Chen, X.; Gonsalves, K.E. Synthesis and Properties of an Aluminum Nitride/Polyimide Nanocomposite Prepared by a Nonaqueous Suspension Process. J. Mater. Res. 1997, 12, 12741286.

(30) Gonsalves K.E.; Jin S.; Baraton, M. Microparticles of Functionalized Polylactide Copolymers. Mater. Res. Soc. Symp. Proc. $1998,501,233-238$.

(31) Hayshi, S.; Nakamori, N.; Hirono, J.; Kanamori, H. Infrared Study of Surface Vibration Modes in MgO Small Cubes. J. Phys. Soc. Jpn. 1977, 43, 2006-2012.

(32) Lucovsky, G.; Yang, J.; Chao, S.S.; Tyler, J.E.; Czubatyj, W. Nitrogen-bonding Environments in Glow-discharge Deposited aSi:H Films. Phys. Rev. B 1983, 28, 3234-3240.

(33) Tsu, D.V.; Lucovsky, G.; Mantini, M.J. Local Atomic Structure in Thin Films of Silicon Nitride and Silicon Diimide Produced by Remote Plasma-enhanced Chemical-vapor Deposition. Phys. Rev. B 1986, 33, 7069-7076.

(34) Hasegawa, S.; Ambutsu, H.; Kurata, Y. Connection Between $\mathrm{Si}-\mathrm{N}$ and Si-H Vibrational Properties in Amorphous SiNx: H Films. Philos. Mag. B 1989, 59, 365-375.

(35) Bustarret, E.; Besouda, M.; Habrard, M.C.; Bruyêre, J.; Poulin, S.; Gujrathi, S.C. Configurational Statistics in a-Si, NyH, Alloys: A Quantitative Bonding Analysis. Phys. Rev. B 1988, 38, $8171-8184$
(36) Scardera, G.; Puzzer, T.; Conibeer, G.; Green, M.A. Fourier Transform Infrared Spectroscopy of Annealed Silicon-rich Silicon Nitride Thin Films. J. Appl. Phys. 2008, 104, $1043101-1043107$.

(37) Asgari, H.; Ashrafizadeh, F.; Toroghinejad, M.R. Influence of Steel Substrate Grain Size on Phase Layers Growth Kinetics and Thickness of Zinc Hot Dipped Steel Sheets. Ironmaking Steelmaking 2009, 36, 145-148.

(38) Amouzou, D.; Guaino, P.; Fourdrineier, L.; Richir, J.B.; Maseri, F.; Sporken, R. Dielectric and Diffusion Barrier Multilayer for $\mathrm{Cu}(\mathrm{In}, \mathrm{Ga}) \mathrm{Sez}$ Solar Cells Integration on Stainless Steel Sheet. Thin Solid Films 2013, 542, 270-275. 
Table 1. Composition and roughness of the $140 \mu \mathrm{m}$-thickness steel substrate

\begin{tabular}{ccccccc} 
Type & $\mathrm{C}(\mathrm{at} \%)$ & $\begin{array}{c}\mathrm{Si} \\
(\mathrm{at} \%)\end{array}$ & $\begin{array}{c}\mathrm{Mn} \\
(\mathrm{at} \%)\end{array}$ & $\begin{array}{c}\mathrm{Cr} \\
(\% \mathrm{at})\end{array}$ & $\begin{array}{c}\mathrm{Fe} \\
(\% \mathrm{at})\end{array}$ & $\begin{array}{c}\mathrm{R}_{\mathrm{a}} \\
(\mathrm{nm})\end{array}$ \\
\hline $\begin{array}{c}\text { AISI } 430^{\text {[a] }} \\
\text { (a] } \text { UNS type number }^{0} \text { (Match with AISI430 ASTM designation) }\end{array}$
\end{tabular}

Table 2. Composition and stability of the nanoparticles inks

\begin{tabular}{|c|c|c|c|c|c|}
\hline \multirow[b]{2}{*}{ Inks } & \multicolumn{3}{|c|}{ Additives (\% w/w) } & \multirow{2}{*}{$\begin{array}{c}\text { Ceramic } \\
\text { materials } \\
(\mathrm{CM}) \\
(\% \mathrm{w} / \mathrm{w})\end{array}$} & \multirow[b]{2}{*}{ Stability } \\
\hline & Total & Dispersant & Plasticizer & & \\
\hline \multicolumn{6}{|c|}{$\mathrm{CM}=\mathrm{Al}_{2} \mathrm{O}_{3}$} \\
\hline $\mathrm{Al}_{2} \mathrm{O}_{3}-\mathrm{I} 1$ & $3 \cdot 3$ & 1.2 & 2.1 & 2.5 & unstable \\
\hline $\mathrm{Al}_{2} \mathrm{O}_{3}-\mathrm{I} 2$ & 4.6 & 1.8 & 2.8 & 2.6 & unstable \\
\hline $\mathrm{Al}_{2} \mathrm{O}_{3}-\mathrm{I}_{3}$ & 2.5 & 2.2 & 0.3 & 3.0 & stable \\
\hline $\mathrm{Al}_{2} \mathrm{O}_{3}-\mathrm{I}_{4}^{[\mathrm{a}]}$ & 2.9 & 2.0 & 0.9 & 2.5 & stable \\
\hline \multicolumn{6}{|c|}{$\mathrm{CM}=\mathrm{AlN}$} \\
\hline AlN-N1 & 2.0 & 1.8 & 0.2 & 3.0 & unstable \\
\hline AlN-N2 & 3.7 & 2.0 & 1.7 & 2.0 & unstable \\
\hline $\mathrm{AlN}^{-N_{3}}$ & 4.6 & 2.8 & 1.8 & 2.0 & stable \\
\hline $\mathrm{AlN}-\mathrm{N}_{4}{ }^{[\mathrm{a}]}$ & $5 \cdot 5$ & 3.1 & 2.4 & 1.8 & stable \\
\hline \multicolumn{6}{|c|}{$\mathrm{CM}=\mathrm{Si}_{3} \mathrm{~N}_{4}$} \\
\hline $\mathrm{Si}_{3} \mathrm{~N}_{4}-\mathrm{S} 1$ & 5.0 & 1.8 & $3 \cdot 5$ & 2.5 & unstable \\
\hline $\mathrm{Si}_{3} \mathrm{~N}_{4}-\mathrm{S}_{2}$ & 5.0 & 2.0 & 3.0 & 2.0 & unstable \\
\hline $\mathrm{Si}_{3} \mathrm{~N}_{4}-\mathrm{S}_{3}$ & 3.9 & 2.1 & 1.8 & 2.0 & stable \\
\hline $\mathrm{Si}_{3} \mathrm{~N}_{4}-\mathrm{S}_{4}^{[\mathrm{a}]}$ & 4.1 & 1.7 & 2.4 & 1.7 & stable \\
\hline
\end{tabular}

${ }^{\text {[a] }}$ It is a mixture of particles with small and big particle size.

Schematic 1. Ceramic ink formulation and barrier layer deposition

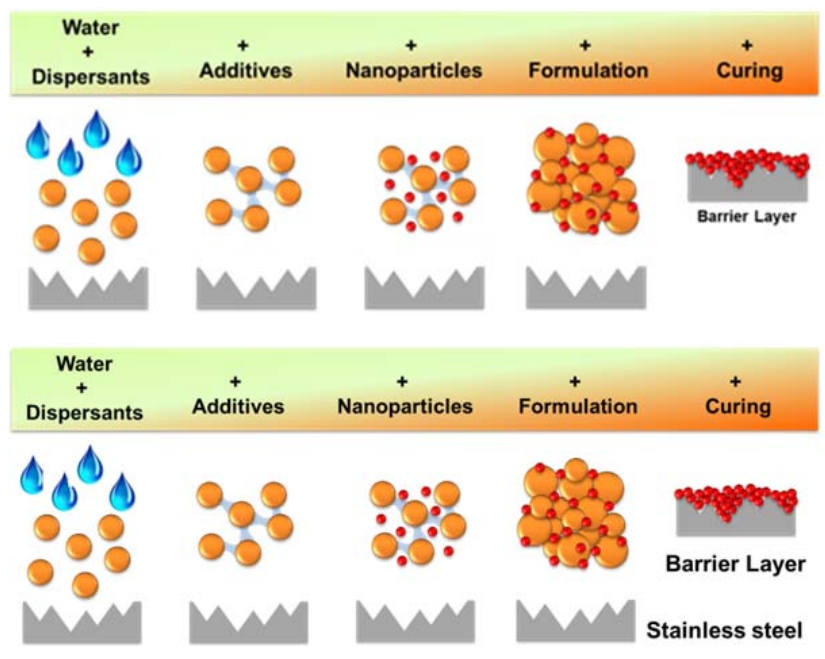



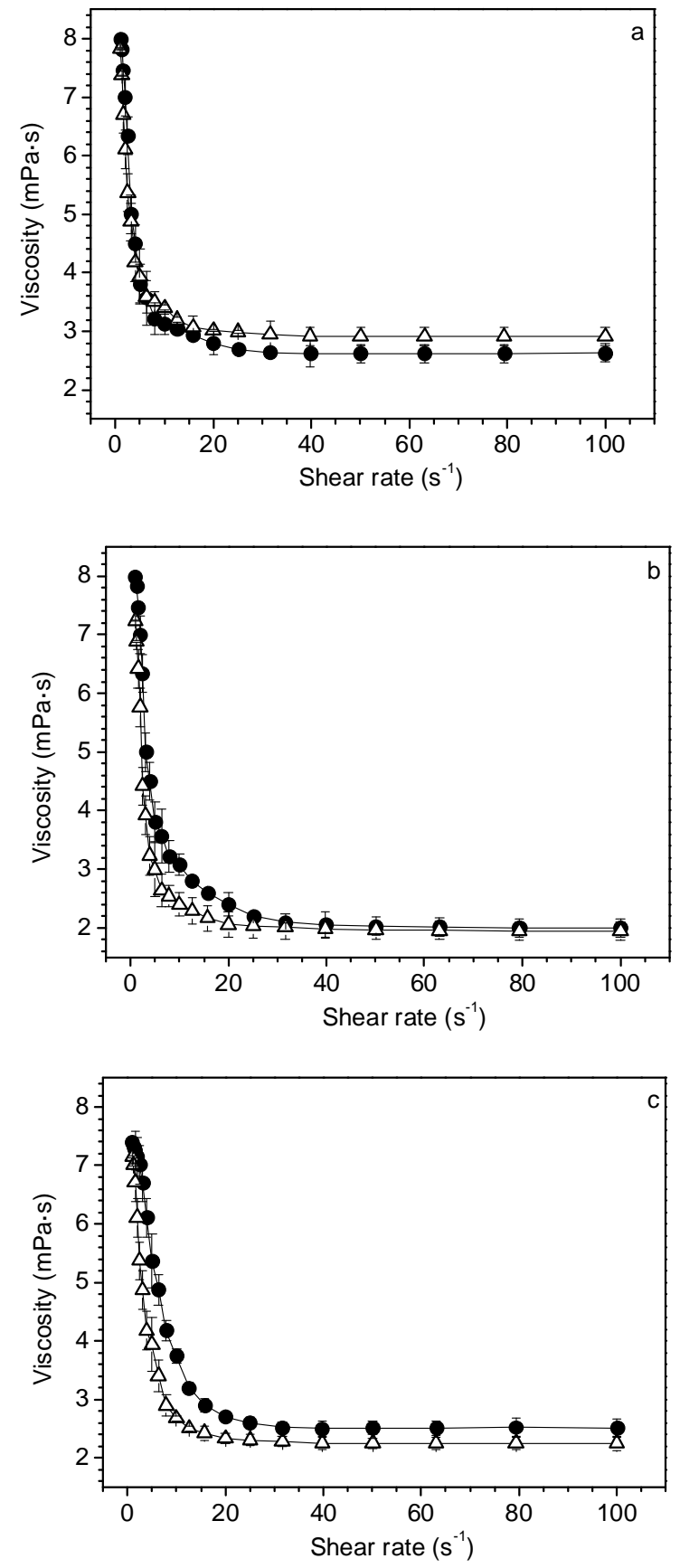

Figure 1. Viscosity curves of the stable ceramic nanoparticles inks: a) $\mathrm{Al}_{2} \mathrm{O}_{3}-\mathrm{I}_{3}$ (solid circles) and $\mathrm{Al}_{2} \mathrm{O}_{3}-\mathrm{I}_{4}$ (open triangles), b) AlN-N 3 (solid circles) and AlN-N 4 (open triangles), and, c) $\mathrm{Si}_{3} \mathrm{~N}_{4}-\mathrm{S}_{3}$ (solid circles) and $\mathrm{Si}_{3} \mathrm{~N}_{4}-\mathrm{S}_{4}$ (open triangles). 

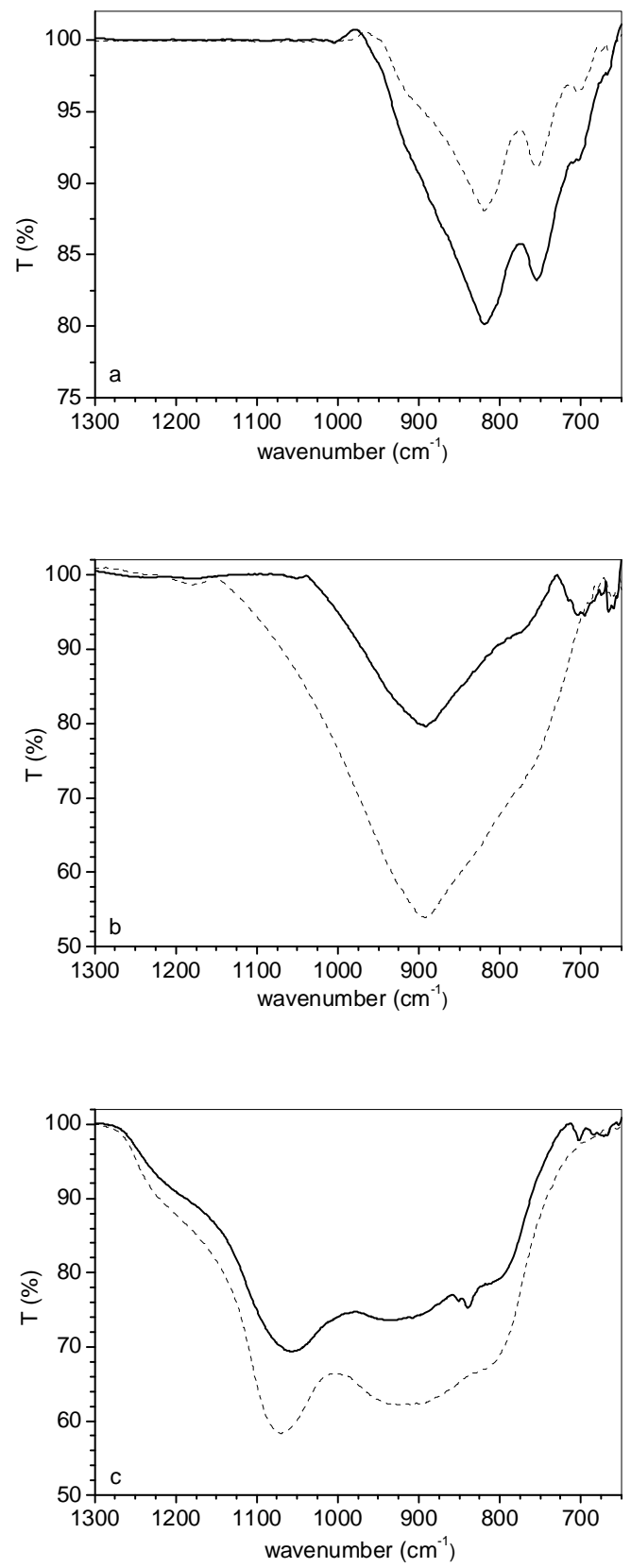

Figure 2. FT/IR spectra of as-received ceramic nanoparticles and of the DSC residues of the stable ceramic nanoparticles with homogeneous particle sizes: a) the pristine as-received aluminum oxide nanoparticles (dash line) and $\mathrm{Al}_{2} \mathrm{O}_{3}-\mathrm{I}_{3}$ (solid line), b) the pristine as-received aluminum nitride nanoparticles (dash line) and AlN$\mathrm{N}_{3}$ (solid line), and, c) the pristine as-received silicon nitride nanoparticles (dash line) and $\mathrm{Si}_{3} \mathrm{~N}_{4}-\mathrm{S}_{3}$ (solid line). 

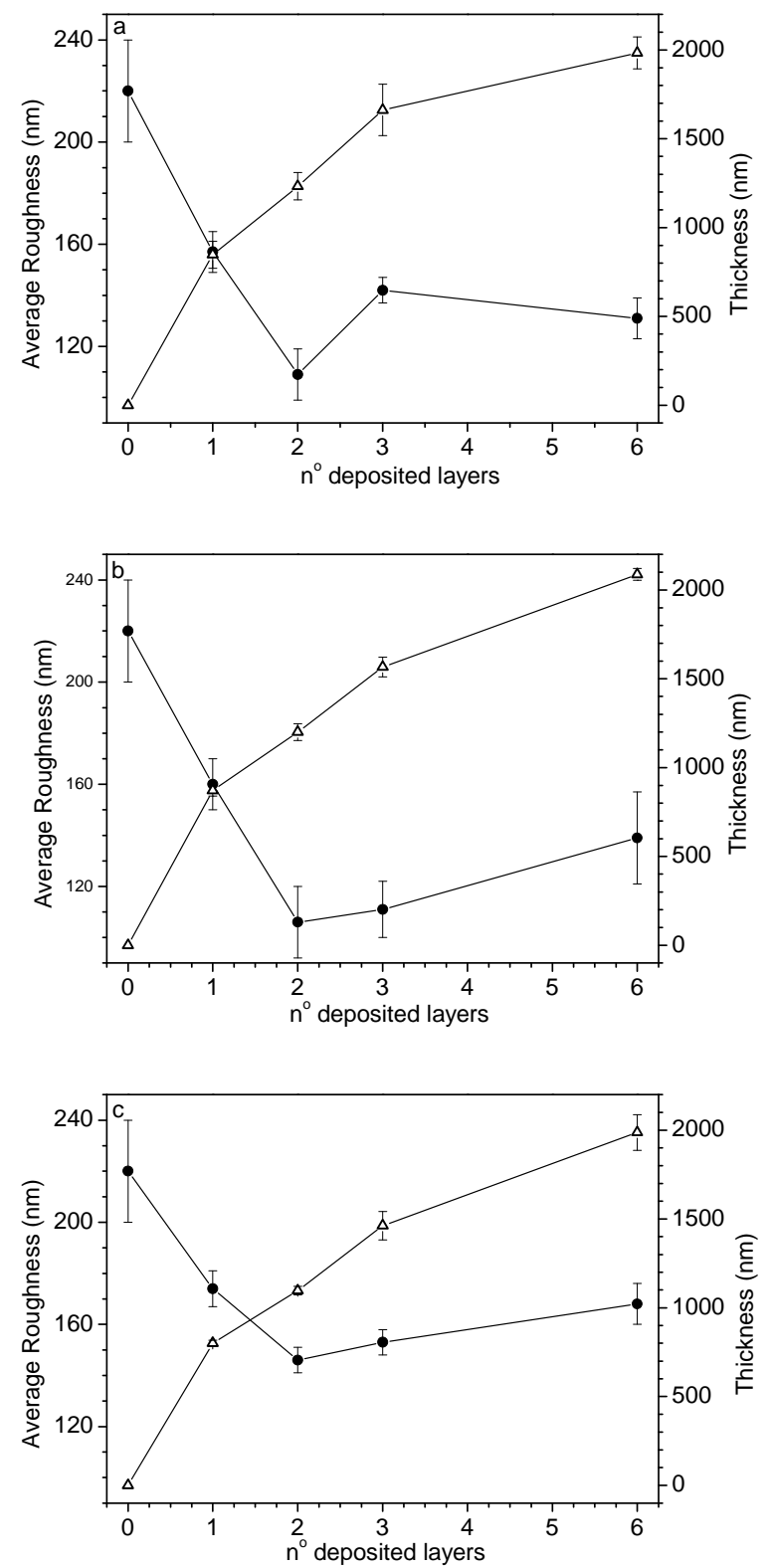

Figure 3. Average roughness (solid circles) and thickness (open triangles) of the stable ceramic barriers with homogeneous particle sizes deposited over stainless steel $\mathrm{AISI}_{43} \mathrm{O}$ : a) $\mathrm{Al}_{2} \mathrm{O}_{3}-\mathrm{I}_{3}$, b) $\mathrm{AIN}-\mathrm{N}_{3}$, and, c) $\mathrm{Si}_{3} \mathrm{~N}_{4}-\mathrm{S}_{3}$. 

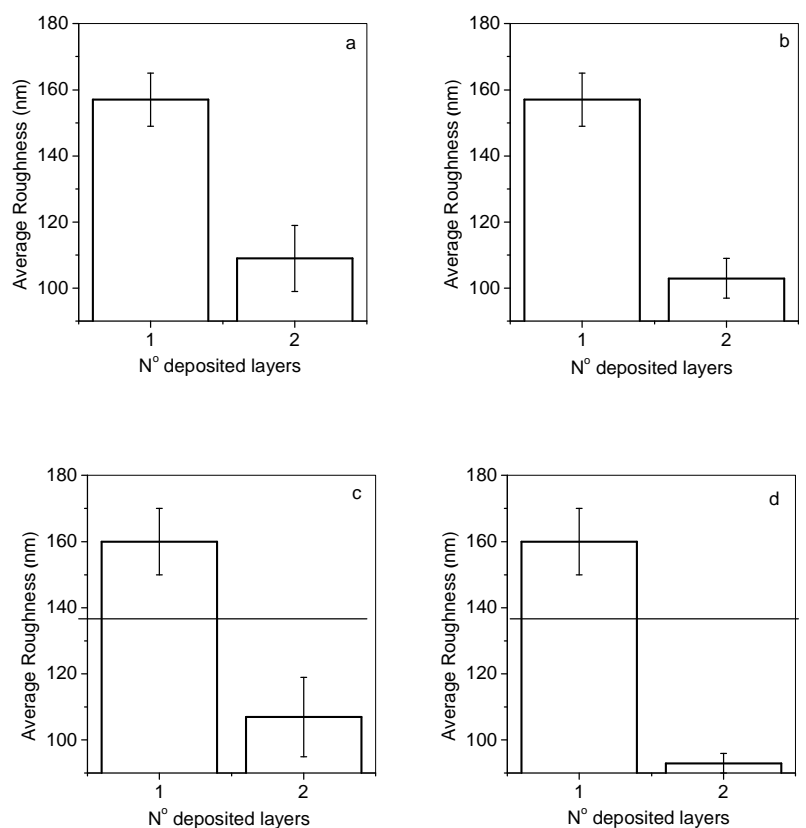

Figure 4. Average roughness and thickness of a bilayer ceramic barrier as a function of the nature of the second layer: a) bilayer $\mathrm{Al}_{2} \mathrm{O}_{3}-\mathrm{I}_{3} / \mathrm{Al}_{2} \mathrm{O}_{3}-\mathrm{I}_{3}$, b) bilayer $\mathrm{Al}_{2} \mathrm{O}_{3}-\mathrm{I}_{3} / \mathrm{Al}_{2} \mathrm{O}_{3}-\mathrm{I}_{4}$, c) bilayer $\mathrm{AlN}-\mathrm{N}_{3} / \mathrm{AlN}-\mathrm{N}_{3}$, and, d) bilayer $\mathrm{AlN}-\mathrm{N}_{3}$ /AlN-N4.

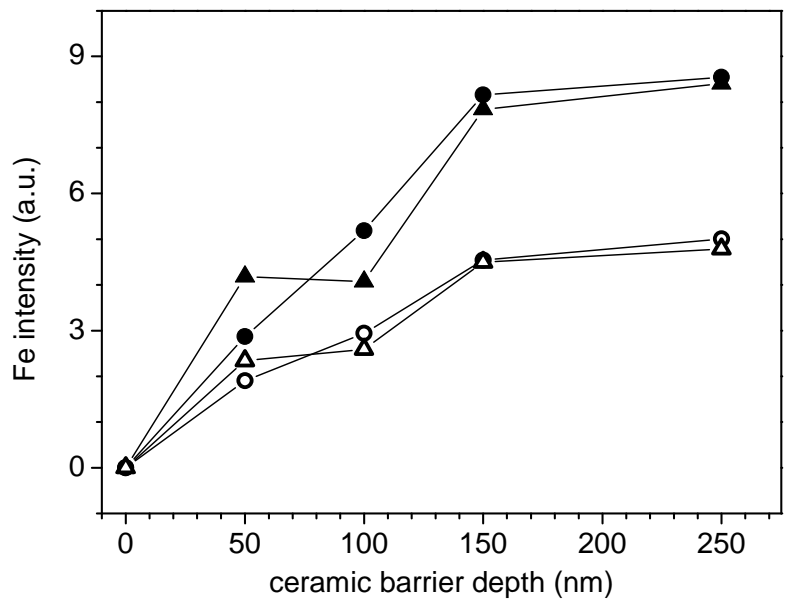

Figure 5. Intensity profile for the Fe $2 \mathrm{p}_{3}$ (solid symbols) and Fe 2p1 (open symbols) XPS signals corresponding to $\mathrm{AIN}-\mathrm{N}_{3} / \mathrm{AlN}-\mathrm{N}_{4}$ bilayer (circles) and $\mathrm{Al}_{2} \mathrm{O}_{3}-\mathrm{I}_{3} / \mathrm{Al}_{2} \mathrm{O}_{3}-\mathrm{I}_{4}$ bilayer (triangles) deposited over AISI 430 stainless steel and heated at $600{ }^{\circ} \mathrm{C}$ during $45 \mathrm{~min}$. 


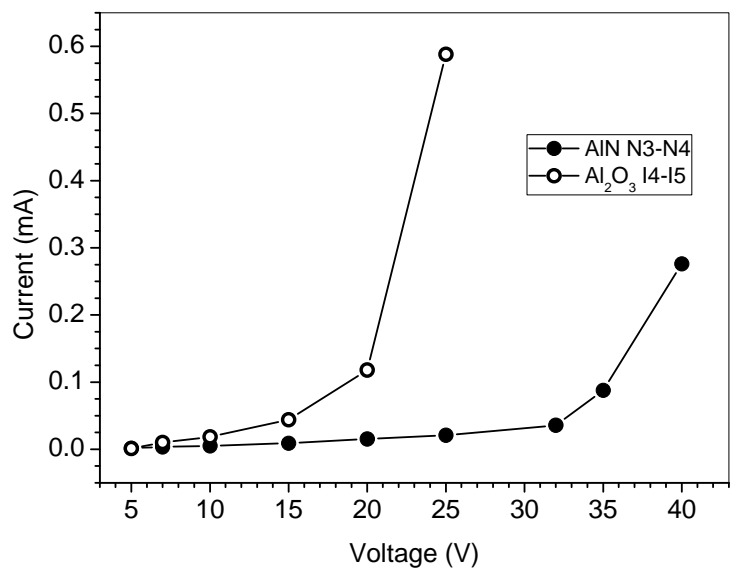

Figure 6. Dielectric breakdown curves corresponding to $\mathrm{AlN}-\mathrm{N}_{3} / \mathrm{AlN}-\mathrm{N}_{4}$ bilayer (solid line) and $\mathrm{Al}_{2} \mathrm{O}_{3}-\mathrm{I}_{3} / \mathrm{Al}_{2} \mathrm{O}_{3}-$ I4 bilayer (dash line) deposited over AISI 430 stainless steel and covered by a molybdenum layer.

\section{TOC FIGURE}

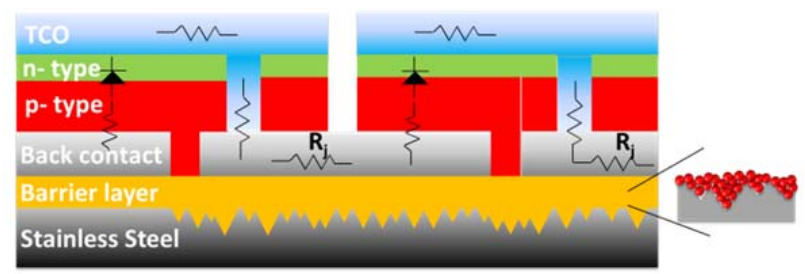

